\title{
Hotels in China: A Comparison of Indigenous and Subsidiaries Strategies
}

\author{
Sam C. Okoroafo (corresponding author) \\ College of Business Administration \\ The University of Toledo \\ 2801 W. Bancroft Street \\ Toledo, Ohio 43606-3390 USA \\ Tel: 419-530-4398Ｅ-mail: Sam.Okoroafo@UToledo.edu \\ Anthony Koh \\ College of Business Administration \\ The University of Toledo \\ 2801 W. Bancroft Street \\ Toledo, Ohio 43606-3390 USA \\ Lulu Liu \\ College of Business Administration \\ The University of Toledo \\ 2801 W. Bancroft Street \\ Toledo, Ohio 43606-3390, USA \\ Xuemei Jin \\ College of Business Administration \\ The University of Toledo \\ 2801 W. Bancroft Street \\ Toledo, Ohio 43606-3390, USA
}

\begin{abstract}
Due to the rapid economic growth in China, tourism and particularly the hotel business has expanded tremendously. The purpose of this research was to compare the strategy and performance of foreign and Chinese owned hotels in China. The findings show that foreign hotels have used selective entry, growth, and management strategies to compete effectively. For instance, incremental growth has been achieved through targeted mergers and acquisitions. Also, foreign run hotels are more profitable than domestic ones.

The Chinese enterprises have been playing 'catch-up', but have begun to adopt standard international hospitality practices combined with selective cultural adjustments to achieve growth. One area where they have an advantage is their willingness and ability to locate all over China.
\end{abstract}

Keywords: Hotels, China, Strategy, Mergers, Tourism, Performance 


\section{Introduction}

Since China's entry in the world trade organization (WTO), it has pursued favorable policies towards foreign investment. Now, in anticipation of the 2010 World Exposition, hotels are expanding rapidly in China. Not only have indigenous (domestic) owned hotels expanded, foreign chains have moved in. Thus, among the world's 300 corporate chains as of yearend2008 ranked by Hotels Magazine (Gale 2009), about 10 percent of them have entered China. Some of the familiar international hotel brand names are InterContinentalHotels (ICH)-UK, Hilton-USA, Global Hyatt-USA, and some mega-chains like Starwood-USA and Accor-France. In fact, Starwood continues to expand in China (Palmeri and Balfour 2009). In 2009, China's stimulus plan seems to have stabilized its economic decline setting the stage for continued growth.

Part of the significance of this topic is that the travel and tourism industry in China has become one of the fastest growing markets in the world (Yu 2005). In 2007, it received 132 million international visitors that generated US\$42 in foreign exchange, marking an increase of 5.5\% and 23.5\% respectively (CNTA 2008a). According to the World Travel and Tourism Council, the growth trend is expected to continue into the next decade (WTTC 2006). The economic crisis could slow this growth rate, but recent indications are that the economy has stabilized partly to the government's stimulus plan. By 2020, the World Tourism Organization forecasts that China will become the world's top tourist destination with 130 million arrivals (Pine and Phillips 2005). Domestic tourism grew to 1.61 billion travelers while revenue increased $24.7 \%$ over 2006 (CNTA 2008a).

The fast growing tourism market has boosted China's hotel development (WTTC 2006). China's hotel industry has grown from a base of only 137 hotels with 15,539 rooms in 1978 (Pine and Phillips 2005) to a level of 5,200 hotels and 700,000 guest rooms currently catering to foreign visitors (CNTA 2008c). When broken down by quality, the number of hotels were; five-star hotels 57 five -star hotels, 157 four-star hotels, 895 three-star hotels, and about 1,600 one- and two-star hotels in China (CNTA 2008c).

The purpose of the paper is to investigate the structure, strategies, and performance of indigenous/domestic and foreign -owned (subsidiaries) hotels in China. This paper first discusses the structures and strategies. Then, performance levels are presented. Finally, the managerial implications and conclusions are discussed.

\section{Theoretical Framework}

The conceptual framework that links structure, strategy and performance is Porter's national competitiveness of nations' theory (popularly referred to as Porter's Diamond). In his framework, he suggests that national competitiveness will anchored along four dimensions-a nation's factor conditions; demand conditions; firm strategy, structure and rivalry; and related and supporting industries (Porter 1990). This study focuses on the anchor pertaining to firm structure, strategy, and rivalry. Most studies (e.g., Stone and Ranchlod (2006) have addressed the macro aspect of his model. By applying this firm level requirement, we are following the example of a more limited number of studies. For instance, Mohan Kathuria (2008) used 


\section{Macrothink Institute ${ }^{\mathrm{TM}}$}

Porter's model to investigate the competitiveness of Indians export industry. One study that has linked the two is Jackson (2006) that linked regional tourism in China to China's socialist economy. So this article contributes by focuses on a critical industry (tourism) in a fast growing and large economy (China).

\section{Strategies for the Hotel Industry in China}

\subsection{Chinese-owned Hotels}

Chinese owned hotels operate under several ownership structures. The ownership arrangements include state-owned hotels (SOH), collective, private, alliance, share-holding co-operative, limited liability, limited liability shares, foreign invested, and Hong Kong, Macau, and Taiwan-invested - see Table 1.

Table 1. Hotel Ownership in China, 2002

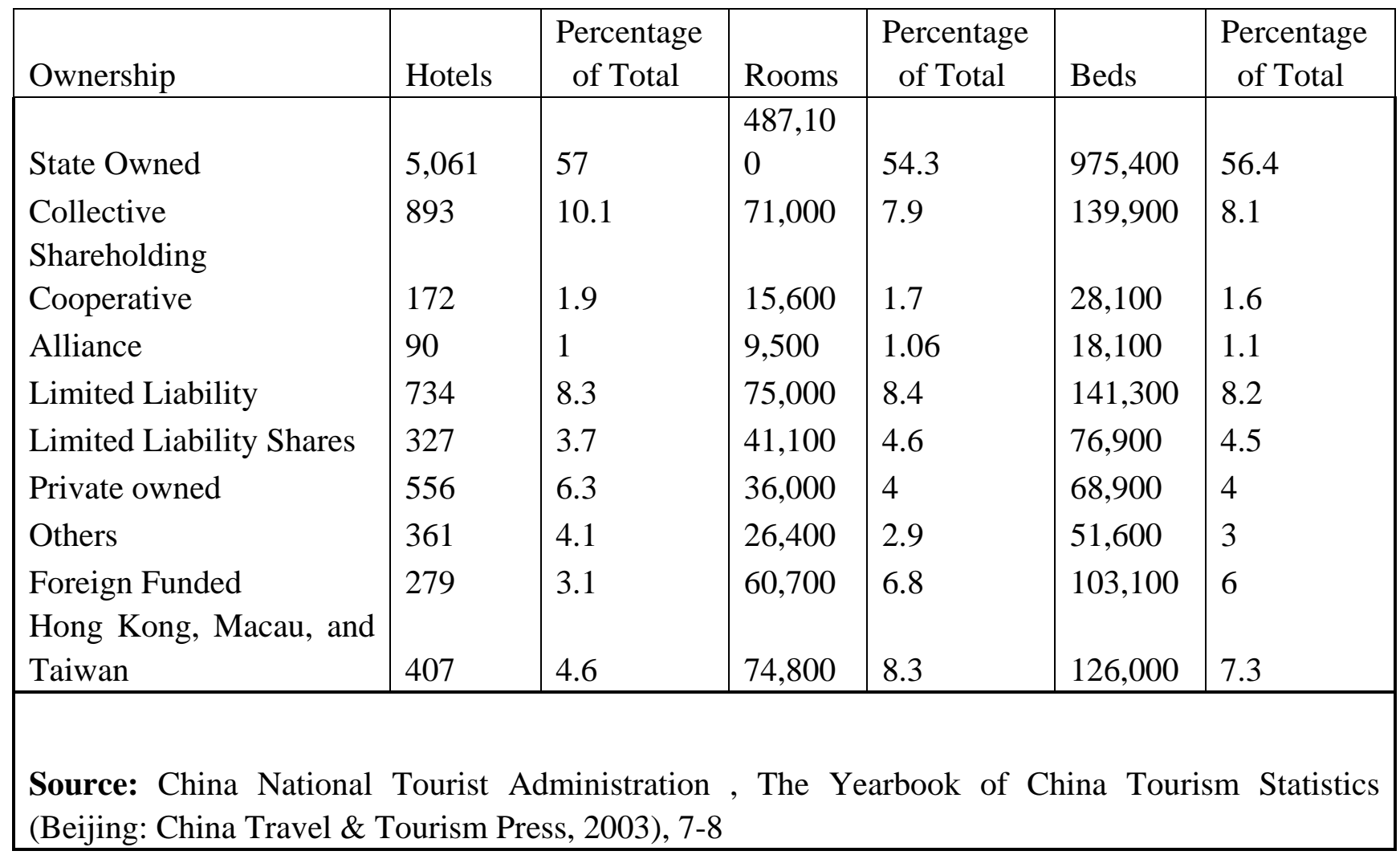

Of the indigenous hotels, more than half of the hotels in China are state-owned (see, Table 1). The state owned hotels are under increased pressure from the government to restructure in order to take viable. They have been hampered by complicated ownership and bureaucratic structures and control (Mak 2008). But some realize the need to grow quickly via mergers. Thus, Zhenjiang Hotel joined the Jinxing Star brand and would focus on the 'economy' market targeting domestic business travelers. To compete effectively, they need to deregulate and raise their standards (Pine 2002). For example, customer service needs to be improved. Because these hotels are state-owned ones, they don't feel the urgency to compete and improve their performance. Their customer service, the conditions of the hotels, and the booking system are not as sophisticated as foreign-owned hotels. Yu and Huimin (2005) 
have identified four problems of Chinese hotel companies: lack of a marketing network, reservation system, managerial expertise, and capital. Much emphasis needs to be put here by China-owned hotels in the future.

However, due to the upcoming Shanghai World exposition in 2010 and competitive pressures, some hotels in China are endeavoring to improve their customer friendliness to some degree. For instance, many famous Chinese owned hotels have begun to create their own websites. Thus their customers can buy tickets online providing greater convenience than before. Having an internet reservation system has been linked to 'customer's willingness to book' (Noone and Mattila 2009). Also, operators like Days Inn- Forbidden City Beijing, and Peninsula Palace Hotel-Beijing are doing their best to compete with the international foreign-owned hotels and to reach more customers. Chinese owned hotels have also become enthusiastic about franchising (Xiao, O’Neill, and Wang 2008). In the 2009 version of the professional standards for hotels which was issued by the China Tourist Hotels Association (CTHA) recently, hotels are allowed, on a voluntary basis to arrange their own check-out schedules (CNTA 2008b). Previous standard required guests to check out by midday, with a half day room rate applicable for checks afterwards till 18:00 hours.

\subsection{Foreign-owned Hotels in China}

To capitalize on the growth, many multinational hotel chains have expanded to China. Among the World's top 300 corporate chains ranked by Hotels magazine (Gale 2009), about $10 \%$ have entered China, e.g. Hilton, Hyatt-USA, Shangri-la-Hong Kong, Marriott-USA, Accor-France, and some mega-chains like Starwood and InterContinentalHotels-UK. Table 2 shows the top ten hotel operators by rooms.

Starwood, whose brands include Sheraton, Westin, St. Regis and W, has 35 hotels in China. Marriott, whose brands include Ritz-Carlton, has 24 hotels open on mainland in China, six more under construction (Zhang et. al 2006). Carlson operates five hotels, all Radissons, in China, and is building five more, including the five-star Regent International. InterContinentalHotels, which owns the Holiday Inn and Crowned Plaza brands, has 20 hotels on the mainland.

Many of the foreign-owned hotels have located near the major cities such as Beijing and Shanghai. However, even small cities such as Ningbo, Hangzhou and Nanjing, where populations exceed 4 million, have drawn development interest. For instance, Carlson is building a Regent International in Ningbo, 100 miles south of Shanghai. But they have stayed away from smaller cities (less than 4 million people).

Foreign-owned hotels entered China using several growth strategies-joint venture, acquisition, mergers, and franchising (Zhang et. al 2005). For example, Marriot-USA enhanced its presence in China after acquisition of Renaissance, which had five mid-priced Ramada hotels in the Chinese cities of Wuhan, Qingdao, Guangzhou, Beijing, and seven upscale New World hotels. Starwood now has a very strong position in China's hotel industry after acquiring Sheraton and Westin. Suzhou International Hotel joined the InterContinentalHotels group and became the Holiday Inn Crowned Plaza Hotel. Accor 
competitive advantages of foreign-owned hotels versus the China-owned hotels are their management scale, management expertise and technology, especially networking by their distribution channels and centralized reservation systems, which can directly lead the overseas tourist to chain hotels (Zhang et al 2005).

\section{Performance Differences between foreign-owned and domestic owned hotels}

Also as Table 2 indicates, the top 10 hotels were dominated by the foreign-owned hotels in 2000. The biggest single operator, Jin Jiang International is from China but the other 6 were foreign-owned hotels which had 80 out of the 143 hotels (60 \%) and 32,036 out the 52,837 rooms (61\%).

Although the foreign hotels have a small number of hotels compared to other types of ownerships, they capitalize on their recognizable international brand reputation and recognition, experience, and advanced hotel management and technology. These enable them to be more profitable than the Chinese operators in terms of room occupancy and revenue per room (see, Table 3), although the latter outnumbers them.

While the number of foreign-owned hotels is less than the state owned hotel with $57 \%$ of the total hotels and $54.3 \%$ of total hotel rooms, they are more profitable (see, Table 3). And even accounting for smaller foreign operators from Hong Kong, Macau, and Taiwan hotels with $4.6 \%$ and $8.3 \%$ of the total hotels and rooms respectively, the occupancy and revenue per room for the foreign owned hotels were much higher than any other hotel ownerships (see, Table 3). For instance, in 2000, foreign invested hotels had $63.64 \%$ of room occupancy which was 9.3\% higher occupancy than state-owned hotel and 4.75\% higher than Hong Kong, Macau, Taiwan hotels. Revenue per room for foreign invested hotels was \$23,116 which was US\$13,506 higher than state -owned hotels and US\$6662 higher than the Hong Kong, Macau, Taiwan hotels.

A hotel industry survey (Zhang, Pine and Lam 2005) conducted by Horwath Asia Pacific for China Tourist Hotel Association from a sample of 248 hotels provided revealing information on hotel performance by comparing the five-star and four-star hotels operated by the three different types of management. The analysis showed that four- and five-star hotels operated by international companies had the best revenue per available room (RevPAR) performance.

RevPAR for four star hotels operated by international companies was $4.1 \%$ higher than domestic chain hotels and $16.3 \%$ higher than domestic independent companies. For five star hotels it was $3.1 \%$ higher than domestic chain managed hotels and $10.5 \%$ higher than domestic independent managed hotels.

The data also shows that five star international managed hotels had slighter higher earnings before interest and taxes (EBITDA) than China-owned hotels- $30.4 \%$ for foreign operators relative to $26.5 \%$ for domestic chain managed hotels, and $23.5 \%$ for domestic independent managed hotels. Department expenses and undistributed expenses between international managed hotels and domestic managed hotels were similar. But international managed hotels spent much more on marketing and energy, and had lower fixed charges on their operations 
while China-owned hotels had higher administrative and general expenses. This outcome exists despite the fact that international managed hotels pay higher compensation and benefits for their expatriate managers.

In summary, foreign-owned hotels have better performance than other hotels, as reflected in higher occupancy rates and higher annual average revenue per room of foreign invested and Hong Kong/Macau/Taiwan-invested properties. This is generally because overseas-invested hotels are usually operated by experienced multinational hotel corporations that have honed their skills in their home and international markets (Yu and Huimin 2005). While most state owned hotels lack strategy in management; they pay

more attention to the daily operations and management procedures, but neglect branding, corporate culture and innovation and, most importantly, the effective use of capital in the market.

Multinational operators are beginning to target the indigenous customers. They are now acceding to the Chinese culture. For instance, employees do not have to understand English to serve customers. Also, foreign-owned hotels are adapting to political and social aspects of Chinese society (Pine and Qi 2004). For instance, they are adapting to guanxi or the networking required to succeed!

\section{Managerial Implications and Prospects of Hotel Industry in China}

This research shows the connectivity between strategy execution and performance. As Phillips (1996) demonstrated; strategic planning affects performance. Our findings would support his. Also, our analysis concurs with Pine and Phillips (2005) that foreign operated hotels are more profitable than domestic ones. This should be concerning to Chinese operators wishing to attract domestic investors.

\subsection{For Chinese Operators}

Since most of the foreign-owned hotels in China have targeted the four and five star segments, local operators can focus on lower star segments. After all, the higher star segments target mostly customers that are overseas travelers and tourist who are familiar with and prefer the home brand names. Another opportunity lies in going after foreign tourists. Marketing research can be used to further segment and understand the needs of the 'value' (not business) or tourist customers.

Opportunities do exist in the expanding upper and middle class Chinese domestic tourists particularly with the recent economic slowdowns. Total number of domestic tourist (Table 4) (CNTA, 2003) rose from US\$639 million in 1996 to US\$870 million in 2003 and revenue from domestic travelers increased from $\$ 42.44$ billion to US\$46.72 billion in 2002. Domestic tourism is expected to continue growing partly due to favorable government policies including the recent economic stimulus spending and the upcoming. 
Table 3. Comparison of Operation Performance by Management Type (in percentages, 2003)

\begin{tabular}{|c|c|c|c|c|c|c|}
\hline \multirow[b]{2}{*}{ Items } & \multicolumn{3}{|c|}{ 4-Star Hotels } & \multicolumn{3}{|c|}{ 5-Star Hotels } \\
\hline & $\begin{array}{l}\text { Int'l } \\
\text { Manage- } \\
\text { ment }\end{array}$ & $\begin{array}{l}\text { Domestic } \\
\text { Chain } \\
\text { Manage- } \\
\text { ment }\end{array}$ & $\begin{array}{l}\text { Independent } \\
\text { Management }\end{array}$ & $\begin{array}{l}\text { Int'l } \\
\text { Manage- } \\
\text { ment }\end{array}$ & $\begin{array}{l}\text { Domestic } \\
\text { Chain } \\
\text { Management }\end{array}$ & $\begin{array}{l}\text { Independent } \\
\text { Management }\end{array}$ \\
\hline $\begin{array}{l}\text { Department } \\
\text { Revenues }\end{array}$ & & & & & & \\
\hline $\begin{array}{l}\text { Per available room } \\
\text { Department }\end{array}$ & 60.7 & 56.6 & 44.4 & 55.2 & 52.1 & 44.7 \\
\hline Expenses & 42.3 & 42.4 & 44.6 & 35.6 & 38.9 & 43 \\
\hline Administrative & 9.7 & 12.8 & 15.3 & 8.4 & 13.4 & 11.3 \\
\hline Marketing & 4.4 & 2.9 & 2 & 5.4 & 2 & 2.4 \\
\hline Energy & 9 & 6.8 & 7.3 & 7.4 & 6.7 & 7.2 \\
\hline Total & 27.9 & 22.6 & 28.4 & 25.3 & 23.4 & 25.3 \\
\hline IBFCMF* & 29.7 & 35 & 27.1 & 39 & 37.8 & 31.8 \\
\hline $\begin{array}{ll}\text { Management } & \text { Fee } \\
\text { (basic } & \text { and }\end{array}$ & & & & & & \\
\hline incentive) & 3 & 3.1 & 6.7 & 3.5 & 3 & 3.5 \\
\hline Fixed charges & 3.8 & 6.4 & 12.1 & 6.3 & 10.5 & 7.8 \\
\hline EBITDA* & 23.3 & 27.9 & 13.5 & 30.4 & 26.5 & 23.5 \\
\hline
\end{tabular}

2010 world exposition. The Chinese government took several steps to encourage the domestic tourist consumption. For example, adding more golden holidays, two days weekend policy and strengthening and implementing the transportation area.

\subsection{For Foreign Operators}

It is essential for foreign-owned hotels considering entering or expanding in China to fully appreciate the political, social and cultural differences they will encounter, which make all aspects of "normal" business practices irrelevant to some degree. Guanxi or networked relationships, particularly, is a concept that is difficult for foreigners to understand, and even foreign companies with a history of working in China still encounter frustration in their efforts to do business. However, the required partnerships with Chinese interests can mitigate this to a certain extent.

\section{Conclusions}

The active growing China economy and favorable government policies provided foreign-owned hotels fertile land to grow up and expand in Chinese market. Foreign-owned hotels, due to their size and international presence enjoy the advantage of economies of scale 
(Zhang et. al. 2005), global recognition and networking, and well - established managerial and technological expertise. This poses challenges and opportunities for the Chinese owned hotels.

Driven by the concomitant growth in demand for business and leisure travel by both Chinese and international visitors and prospects of the World Exposition, both China-owned hotels and foreign-owned hotels have great potential for future growth. Although there is a continuing demand in the hotel area, the underlying threat of oversupply is also considerable.

There is a symbiotic existence between foreign and domestic owned hotels. While foreign-owned hotels push the mainland China-owned hotels to meet the global international standards, the latter causes the former to adapt culturally. But the anticipated growth in both international and domestic travelers provides market opportunities to both China-owned and foreign-owned hotels.

\section{References}

Chao, L. (2008). IHG to Franchise Hotels in China. Wall Street Journal - Eastern Edition, 251:23, D5.

CNTA (2008a) . China Tourism Statistics Bulletin-2007. [Online] Available: http://www.cnta.gov.cn

CNTA (2008b). Chinese Hotels to Have Flexible Check-out Schedules. [Online] Available: http://www.cnta.gov.cn

CNTA (2008c) . Travel in China - Hotels and Accommodation. [Online] Available: http://www.cnta.gov.cn

CNTA (2003) . Total Number of Domestic Tourism from 1996-2003. [Online] Available: http://www.chinatour.com

Gale, D. (2009). World's Largest Hotel Companies: Corporate 300 Chart. [Online] Available: http://www.hotelsmag.com/index.asp?layout=articlePrint\&articleID=CA6667503\&article_pr efix=CA\&article_id=6667503 6/26/09

Graf, N. (2009). Stock Market Reactions to Entry Mode Choices of Multinational Hotel Firms. International Journal of Hospitality Management, 28:2, 236-244.

Jackson, J. (2006). Developing Regional Tourism in China: The Potential for Activating Business Clusters in a Socialist Market Economy. Tourism Management, 27(4), 695-706.

Mak, B. (2008). The Future of the State-owned Hotels in China; Stay or Go? International Journal of Hospitality Management, 27:3, 355-367.

Magnini, V. (2009). An Exploratory Investigation of the Real-Time Training Modes used by Hotel Expatriates. International Journal of Hospitality Management, 28:4, 513-518.

Mohan Kathuria, L. (2008). An Analysis of Competitiveness of Indian Clothing Export Sector Using Porter's Model, Journal of International Business, 3:4, 39-46. 
Noone, B \& Mattila, A. (2009). Hotel Revenue Management and the Internet: The Effect of Price Presentation Strategies on Customers' Willingness to Book. International Journal of Hospitality Management, 28:2, 272-279.

Palmeri, C. \& Balfour, F. (2009). Starwood is Blanketing China. BusinessWeek, :4145, 56-57.

Pine, R. \& Phillips, P. (2005). Performance Comparisons of Hotels in China. International Journal of Hospitality Management, 24:1, 57-73.

Pine, R \& Qui, P. (2004). Barriers to Hotel Chain Development in China,” International Journal of Contemporary Hospitality Management, 16:1, 37-44.

Pine, R. (2002). China's Hotel Industry. Cornell Hotel and Restaurant Administration Quarterly, 61-70.

Pine, R, Zhang, H. \& Qi, P. (2000). The Challenges and Opportunities of Franchising in China's Hotel Industry," International Journal of Contemporary Hospitality Management, 3000-3007

Porter, M. (1990), The Competitiveness Advantage of Nations (New York: Free Press)

Stone, H. \& Ranchlod, A. (2006). Competitive Advantage of a Nation in the Global Arena: A Quantitative Advancement to Porter's Diamond Applied to the UK, USA, and BRIC nations. Strategic Change, 15:6, 283-284.

WTTC (2006). China Travel \& Tourism Climbing To New Heights: The 2006 Travel \& Tourism Economic Research. World Travel and Tourism Council [Online] Available: http://www.wttc.org

Xiao, Q, O’Neill, \& Wang, H. (2008). International Hotel Development: A Study of Potential Franchisees in China. International Journal of Hospitality Management, 27(3), 325-336.

Yu, R. (2005). Western Hotel Chains Build on China's Change. USA Today, Money Section, $4 \mathrm{~b}$

Yu, L. \& Huimin, G (2005). Hotel Reform in China. Cornell Hotel and Restaurant Quarterly, 152-169

Zhang, H., Pine, R. \& Lam, T. (2005). Tourism and Hotel Development in China. NY, NY: The Haworth Hospitality Press and International Business Press. 